\title{
PERFORMANCE OF DIFFERENT FERMENTATION METHODS AND THE EFFECT ON COFFEE QUALITY (Coffea arabica L.)
}

\author{
Aida Esther Peñuela-Martínez ${ }^{1}$, Arley David Zapata-Zapata ${ }^{2}$, Diego Luis Durango-Restrepo ${ }^{3}$
}

(Received: May 29, 2018; accepted: August 27, 2018)

\begin{abstract}
Fermentation of coffee mucilage is a spontaneous process caused by microorganisms growing in the environment, which is influenced by factors such as the coffee variety, climate and fruit maturity. These external factors play an important role in fermentation evolution because they have effect on the microorganism activity and the time for substrate transformation. The aim of this research was to asses different fermentation wet process and evaluate their effect on coffee quality (C.arabica), as well as on organic acid concentrations and volatile organic compounds content, in the green coffee beans. The study was divided in two phases, one in which the pulping time was delayed and the fermentation methods were modified, and the second phase in which a bioreactor was used to control the $\mathrm{pH}$ and temperature of the coffee mass during fermentation. Two control treatments were used: without fermentation (mechanical removal of mucilage) and the traditional fermentation done in the farm. Significant differences in coffee quality were observed. The best quality was obtained from the treatments that used short process times and low temperatures. The concentrations of acetic, lactic and citric acids between the treatments and the control treatments were different. Higher contents of esters and ketones were found in the coffee that obtained the highest quality. The assessed processes lead to the conclusions that it is possible to improve coffee quality throughout introducing changes in the fermentation process, as well as modulating the acidity and fragrance of the final product.
\end{abstract}

Index terms: Fermentation processes, special attributes, organic acids, volatile organic compounds.

\section{DESEMPENHO DE DIFERENTES MÉTODOS DE FERMENTAÇÃO E O EFEITO NA QUALIDADE DO CAFÉ (Coffea arabica L.)}

RESUMO: A fermentação da mucilagem de café é um processo espontâneo causado por microrganismos que crescem no meio ambiente, influenciado por fatores tais como a variedade, o clima e a maturação dos frutos. Estes fatores externos desempenham um papel importante na evolução da fermentação porque determinam atividade dos microrganismos e o tempo da transformação do substrato. O objetivo do presente trabalho foi avaliar o efeito de diferentes modificações no processo de fermentação e avaliar o seu efeito na qualidade do café (C. arabica), assim como, nas concentrações de ácidos orgânicos e no teor de compostos orgânicos voláteis, no café verde. O estudo foi dividido em duas fases, uma em que o tempo de despolpamento foi atrasado e os métodos de fermentação modificados, e a segunda fase em que foi utilizado um biorreator para controlar o pH e a temperatura da massa de café durante a fermentação. Utilizaram-se dois tratamentos de controle: sem fermentação (remoção mecânica de mucilagem) e a fermentação tradicional feito na exploração agrícola. Foram observadas diferenças significativas na qualidade do café. A melhor qualidade foi obtida a partir dos tratamentos que utilizaram os tempos de processo curtos e baixas temperaturas. A concentração de ácidos acético, láctico e cítrico entre os tratamentos que usaram a fermentação e os controles foi diferente. Maiores teores de ésteres e cetonas foram encontrados no café que obteve maior qualidade. Os processos avaliados permitiram concluir que é possível melhorar a qualidade do café através da introdução de alterações no processo de fermentação, bem como modular a acidez e a fragrância do produto final.

Termos para indexação: Processos de fermentação de café, qualidade do café, ácidos orgânicos, compostos orgânicos voláteis.

\section{INTRODUCTION}

Growing specialty coffee market is a response of customers desiring to pay more for unique attributes in the beverage. In that regard, the fermentation stage plays one of the most important roles due the wide variety of modifications that have effect on the flavors and tastes (FOLMER 2014, LEE et al., 2015; POLTRONIERI; ROSSI, 2016). Coffee quality is an outcome not only of the intrinsic grain characteristics but for a combination of the environmental characteristics of the place it is grown (altitude, climate, and soils, among others), the ripeness at which it is harvested, and the post-harvest process carried out (JOËT et al.,
2010; TOLEDO et al., 2016). The wet method, which is a post-harvest process used to maintain the mildness of the Arabica coffee, involves the mechanical removal of the fruit skin (exocarp or pulp) to expose the jelly layer (mesocarp or mucilage) adhered to the bean's surface. Then pulped coffee is put into tanks to perform mucilage degradation by spontaneous fermentation, to facilitate mucilage removal by washing. In the mucilage degradation process, microorganisms in the environment use mucilage as a substrate for their metabolic processes to generate organic acids among others. The wet process of coffee is associated with a higher acidity, which leads to a

1,2,3 Universidad Nacional de Colombia - Sede Medellín - Escuela de Química - Carrera 65 \# 59A-110 - Medellín - Código Postal050034 -Colombia - aepenuelam@unal.edu.co, adzapata@unal.edu.co,dldurango@unal.edu.co 
better cup qualification. This process is widely used in different coffee-growing countries to enhance coffee quality, because it plays a significant role in modulating the quality since the variation of each factor contributes to the composition of coffee, the formation of the aroma and the flavor precursor compounds that can produce different sensory experiences (JOËT et al., 2010; SUNARHARUM; WILLIAMS; SMYTH, 2014). Since acidity and fragrance are two important attributes of the sensory analysis, correlating the fermentation practices with the organic acids and volatile organic compounds (VOCs) in green coffee beans is crucial because these compounds are precursors of other compounds formed through roasting, which are important for the development of the taste and aroma of coffee (TOLEDO et al., 2016).

Studies on coffee fermentation have been performed with the aim of improving the wet process. For example, some research works have reduced the fermentation time (SILVA et al., 2013; PEÑUELA et al., 2010; TAI et al., 2014), inoculated microorganisms to improve quality (LIN, 2016; PEREIRA et al., 2015, PEREIRA et al., 2016; VELMOUROUGANE et al., 2008), or controlled the process to avoid deterioration of the product quality (JACKELS; JACKELS, 2005; PENUELA et al., 2012). However, the effect of different coffee fermentation methodologies on both quality and chemical composition is scarce. Coffee growers sometimes use traditional practices to conduct fermentation, which affect the development of the process and causes differences in coffee quality. These practices include maintaining the coffee fruits for longer times before pulping, adding up freshly pulped coffee to coffee with a fermentation process in progress and adding water during processing. Temperature and $\mathrm{pH}$ are critical variables in the evolution of fermentation. When spontaneous fermentation occurs, the mass temperature of coffee increases between 4 to $8^{\circ} \mathrm{C}$, and $\mathrm{pH}$ decreases down to values between 5.5 to 4.0 , or even lower (AVALLONE et al., 2001; CORREA et al., 2014; CORDOBACASTRO et al., 2016; JACKELS; JACKELS, 2005; VELMOUROUGANE, 2013). However, the effect of controlling these parameters during fermentation on the coffee quality is unknown.

The coffee quality could be improved changing the fermentation stage, which would produce better prices in the market. The aim of the present paper was to determine the effect of some common practices carried out by coffee growers in both the beverage quality and the chemical composition of the beans. Furthermore, the effect of maintaining the $\mathrm{pH}$ and temperature constant during the fermentation process using a bioreactor was evaluated.

\section{MATERIALS AND METHODS}

There were used coffee fruits of C. arabica. (Caturra variety) from a plantation located at an altitude of $1.940 \mathrm{~m}$ in Ciudad Bolívar, AntioquiaColombia. A vertical cylinder pulper was used to remove the coffee fruit outermost skin, with no use of water for the process itself, as well as for the transportation of the pulp and pulped beans. An after-pulping size classification was performed in a cylindrical screen. The research work was divided into two phases. The first phase consisted in assessing the different fermentation strategies, to obtain a higher coffee quality and choose the best strategy to be used in the second phase. In the second phase, a bioreactor was used to control $\mathrm{pH}$ and temperature within the mass of coffee during fermentation. The $\mathrm{pH}$ and temperature of coffee mass were monitored during the fermentations.

In order to run the first phase and determine the fermentation strategy that results in better coffee quality, two factors were evaluated; pulping delaying time and the fermentation method. The two delaying times were $\mathrm{t} 1(6 \mathrm{~h} \pm 1 \mathrm{~h})$ and $\mathrm{t} 2(16 \mathrm{~h} \pm$ 1h), meaning the pulping at the same day and pulping a day after harvesting, respectively. The fermentation methods were: fermentation for 24 h (F24), fermentation for $48 \mathrm{~h}$ with an addition of freshly pulped coffee at hour 24 (MF), and fermentation for $72 \mathrm{~h}$ with addition of freshly pulped coffee at hour 24 and addition of water at hour 48 (WF). These fermentations were evaluated to allow changes in the microbial activity conditions. The experimental unit randomly assigned to each treatment was $60 \mathrm{~kg}$ of pulped coffee. Two control treatments were used: a negative control (without Fermentation), which is the mechanical removal of mucilage of pulped coffee, and a standard control (traditional fermentation), which consists in performing a spontaneous fermentation during $16 \mathrm{~h}$. Once the treatment with the best results was selected, the first phase was concluded.

To conduct the second phase in the bioreactor, it was selected the treatment of the first phase that generated the highest final score in the sensory analysis. The stainless-steel bioreactor was a $35 \mathrm{~L}$ stirred fermenter tank with a water jacket to heat-up or cool-down the coffee mass, according to the desired temperature (Designed by Centricol ${ }^{\circledR}$, Colombia). With the characteristics and physical properties of the coffee mass under a fermentation process, it was selected a helical belt propeller because it causes low shear stresses to viscous fluids with suspended particles. 
The agitation was performed by one minute every two hours. A randomized experimental design, with two temperature levels $\left(17^{\circ} \mathrm{C}\right.$ and 23 ${ }^{\circ} \mathrm{C}$ ) and three $\mathrm{pH}$ levels (without control, 5,0 and $4,0)$ was followed. The experimental unit consisted of $30 \mathrm{~kg}$ of pulped coffee. One standard control, fermentation for $24 \mathrm{~h}$ was adopted. During the first phase, the environment temperature varied between 17,0 and $22{ }^{\circ} \mathrm{C}$, while it varied between 15,2 and $28,6{ }^{\circ} \mathrm{C}$ during the second phase.

For the sensory analysis, the coffee samples from the fermentation treatments were washed to remove the degraded mucilage. Then, they were dried with forced air at $50{ }^{\circ} \mathrm{C}$ down to a moisture of $11 \% \pm 1,0 \%$ w.b. Finally, an expert panel with five trained coffee cuppers with Q-Grader certification evaluated the samples. The coffee cuppers considered all the important flavor attributes of coffee using the Specialty Coffee Association of America protocol for roasting, preparation and analysis (SCA, 2015). Each of the five cuppers evaluated five cups of each coffee sample. The attributes for the sensory profile were fragrance/ aroma, uniformity, cleanliness, sweetness, flavor, acidity, body, aftertaste, balance and overall impression. Each attribute was evaluated in the 10 -point scale and the final qualification is given in a 100-point scale. The response variable was the final score, which was obtained by adding the individual scores given to each attribute to represent the overall coffee quality. The highest final score indicates the best classification of coffee quality. The median of the attributes and the final score was chosen as a robust measure of central tendency for this type of analysis.

In order to perform the chemical analysis, washed coffee samples of $50 \mathrm{~g}$ were taken and then stored at $-20^{\circ} \mathrm{C}$, until analysis. To keep the coffee composition unaltered, the samples of coffee beans were washed and frozen at $-80{ }^{\circ} \mathrm{C}$ overnight and then lyophilized for $48 \mathrm{~h}$ until moisture went down to a range between $9 \%$ and $13 \%$ w.b. Subsequently, the samples were subjected to cryogenic grinding $(<100 \mu \mathrm{m})$. Ground samples were kept frozen at $-20{ }^{\circ} \mathrm{C}$ in plastic containers until the analysis. The moisture content of the ground coffee was estimated after drying 0,2 $\mathrm{g}$ completely in an oven at $105^{\circ} \mathrm{C}$ for $24 \mathrm{~h}$ (International Organization for Standardization ISO:6673, 2003).

For the organic acid extraction, the procedure described by Evangelista et al., (2014) was used, including the following modifications:
$0,5 \mathrm{~g}$ of the sample was combined with $5,0 \mathrm{~mL}$ of Milli-Q water. Then, the mixture was set to vortex for $2 \mathrm{~min}$ and allowed to reach steady state for 10 min before undergoing a double centrifugation at $10000 \mathrm{~g}$, at $4{ }^{\circ} \mathrm{C}$ during $10 \mathrm{~min}$. To clarify the samples, the Carrez reagent (RODRIGUES; BRAGAGNOLO, 2013) was added and the samples were centrifuged again for $5 \mathrm{~min}$ at $1585 \mathrm{~g}$. The supernatant was micro-filtered through a $0,45 \mu \mathrm{m}$ nylon membrane and stored at -20 ${ }^{\circ} \mathrm{C}$ until analysis. The samples were prepared in triplicates. The contents of the malic, citric, lactic, acetic, succinic and quinic acids were determined by HPLC using a Shimadzu Prominence 20 A chromatograph, which was equipped with a diode array detector, using a column Synergi $4 \mathrm{U}$ HydroRP 80 A $(250 \mathrm{~mm} \times 4,6 \mathrm{~mm})$ operated at $25^{\circ} \mathrm{C}-29$ ${ }^{\circ} \mathrm{C}$. Acids were eluted at a flow rate of $0,7 \mathrm{~mL} /$ min, with the mobile phase buffer phosphate at $20 \mathrm{mM}$ and $\mathrm{pH}$ level of 2,90 for $45 \mathrm{~min}$. The injection volume was $20 \mu \mathrm{L}$. The organic acids were monitored at a wavelength of $205 \mathrm{~nm}$. The identification was performed by co-elution with analytical standards of each acid (purity $>99 \%$, Sigma-Aldrich, Pennsylvania, USA). Quantification was conducted using calibration curves (peak area vs. compound concentration) for concentrations of 5-300 mg/L. All concentration curves presented with high linearity (correlation coefficient greater than 0.99).

In order to determine differences in volatile organic compounds, the samples corresponding to the control treatments and the highest and lowest final score in sensory analysis were chosen. For extraction of volatile compounds, $0,5 \mathrm{~g}$ of ground coffee were placed in Solid Phase Microextraction (SPME) vials. The samples were placed for 30 min in an oven at $35^{\circ} \mathrm{C}$ to reach sample headspace equilibrium. The compounds were trapped by means of Carboxen/poly(dimethylsiloxane) (CAR/PDMS) type $75 \mu \mathrm{m}$ SPME fibre (Supelco Co.). Desorption process was done in the $\mathrm{GC}$ injection port for $3 \mathrm{~min}$ at $280{ }^{\circ} \mathrm{C}$ in splitless mode. The separation process for the chromatography analysis was performed with a DB-WAX capillary column measuring $50 \mathrm{~m} \times 320 \mu \mathrm{m}$ in an Agilent HP 6890 GC chromatograph, which coupled to Agilent HP 5973 Mass Spectrometer where detection was done. The carrier gas was helium with a flow was $1,2 \mathrm{~mL} / \mathrm{min}$. The column temperature was programmed from 40 to $110^{\circ} \mathrm{C}$ at $7^{\circ} \mathrm{C} / \mathrm{min}$ and then at $10^{\circ} \mathrm{C} / \mathrm{min}$ until $280{ }^{\circ} \mathrm{C}$. 
The mass were scanned from 40 to $550 \mathrm{amu}$ at a scanning rate of $2,89 \mathrm{scans} / \mathrm{s}$. Ionization method used was electronic impact with an ionization energy of $70 \mathrm{eV}$. The compound identification was performed in accordance with the mass spectrum comparison with the databases (Wiley 275 Mass Spectral Data and NIST 98 Mass spectral Library). The probability of this relationship in all cases was greater than $80 \%$. Furthermore, the concentration was related to the area under the curve of each chromatographic peak.

Data analysis was conducted using the Statistical Analysis System program (Cary, NC, USA) for ANOVA $(\alpha=0,05)$. The Tukey and Dunnett tests, with a $5 \%$ significance level were applied to compare the treatments and controls, which were evaluated separately in order to obtain the treatment with the best quality. Multidimensional scaling (MDS) analyses were applied to the means of the organic acids and volatile organic compounds using the $\mathrm{R}$ program (version 3.3.1.).

\section{RESULTS AND DISCUSSION}

According to the sensory analysis (Table 1), the final score obtained in all treatments was higher than 80 points; the coffee obtained in this study was classified as Premium according to the SCA scale. The control treatments assessed in this research showed that quality was associated with the intrinsic characteristics of the Arabica species, wet process and growth conditions, such as soil and climate (JOËT et al., 2010). ANOVA showed that the interaction of factors, such as pulping delaying time and fermentation methods, affected the final coffee quality $(p=0,0383)$. The treatments applied indicated a higher quality than the standard and negative controls.

In general, the temperature of the mass of coffee in the fermentation processes was between 18 and $22{ }^{\circ} \mathrm{C}$ and the $\mathrm{pH}$ values decreased from 5,89 to 3,77 . The lowest final score in quality was obtained by the treatment with the longer time (t2WF); this fermentation had a final $\mathrm{pH}$ value below 4,00 . Other treatments with high qualifications showed final $\mathrm{pH}$ values above 4,10 . According to Jackels and Jackels (2005), the final coffee quality is better when the $\mathrm{pH}$ value is higher than 4,00 at the end of the fermentation.

Uniformity, cleanliness and sweetness obtained the maximum score (10 points) in all samples (Data not shown). Therefore, neither astringency or 'green' flavors nor negative impressions were found. Moreover, this indicate the consistency of flavor in the five cups of each several coffee sample considered by the coffee cuppers.

Differences in the other attributes scores were detected between the samples with high final scores and the standard and negative controls, mainly in acidity, fragrance, body and flavor (Table 1). Treatments with $\mathrm{t} 2$ tend to obtain the highest score in body and fragrance attributes. The main organoleptic descriptors were fruity, with citric and red berries notes, although the cuppers were not consistent. This indicates the variations of the perceptions of the panelists, which was also noticed by Pereira et al., (2017). Acidity and fragrance can be related with microbial activity because of organic acids and aromatic compounds production. The processes occurring naturally within the fruit affect the coffee beverage. Therefore, the longer time between harvest and pulping process could be influencing these results. For example, the differences in characteristics, such as sweetness and body, have been identified to depend on the type of process. When the fruit remains whole in the drying process, the coffee beverage has a high sugar content and full body because of the metabolism of the beans (KNOPP et al., 2006). Moreover, the different pulping delaying times have been assessed and found to have no negative effects on coffee quality, in the specific varieties and environmental conditions (CAIXETA et al., 2013).

The treatment t2-F24 presented significant differences in quality with the control treatments and was classified as Excellent specialty coffee according to SCA, as it obtained a higher final score of 86 points. Therefore, this treatment was selected to perform the fermentation in the bioreactor with $\mathrm{pH}$ and temperature control.

Fermentations with $\mathrm{pH}$ and temperature control was conducted for $24 \mathrm{~h}$ on coffee pulped the day after harvest $(16 \mathrm{~h} \pm 1 \mathrm{~h})$ (Table 2). The ANOVA showed a significant effect of the interactions of $\mathrm{pH}$ and temperature on coffee quality $(p=0,0347)$. The final score tends to be higher when the fermentation was conducted at low temperature. However, neither $\mathrm{pH}$ control nor temperature control produce significant effect on coffee quality separately $(p=0,2983$ and $p=0,1587$ respectively). The fermentation processes in the bioreactor showed that the final score was significantly high in the coffee obtained at $17^{\circ} \mathrm{C}$ and $\mathrm{pH} 5,00$, having the highest qualifications in acidity, fragrance and body. 
TABLE 1 - Average values in sensory quality, final score and acidity, fragrance/aroma, body and flavor in coffee samples from the fermentations with different conditions of coffee processes.

\begin{tabular}{|c|c|c|c|c|c|c|}
\hline $\begin{array}{c}\text { Time before } \\
\text { pulping }\end{array}$ & $\begin{array}{c}\text { Fermentation } \\
\text { method }\end{array}$ & Final score & Acidity & $\begin{array}{c}\text { Fragrance/ } \\
\text { aroma }\end{array}$ & Body & Flavor \\
\hline \multirow{3}{*}{$\mathrm{t} 1$} & $\mathrm{~F} 24$ & $84,25 \pm 0,71$ & $7,75 \pm 0,21$ & $7,88 \pm 0,30$ & $7,75 \pm 0,35$ & $7,81 \pm 0,41$ \\
\hline & $\mathrm{MF}$ & $84,94 \pm 2,21^{*, * *}$ & $7,94 \pm 0,34$ & $7,88 \pm 0,13$ & $7,69 \pm 0,36$ & $8,00 \pm 0,21$ \\
\hline & WF & $85,50 \pm 0,35^{* *}$ & $8,00 \pm 0,09$ & $7,94 \pm 0,26$ & $7,88 \pm 0,27$ & $8,19 \pm 0,19$ \\
\hline \multirow{3}{*}{$\mathrm{t} 2$} & $\mathrm{~F} 24$ & $86,31 \pm 0,09^{*, * *}$ & $7,94 \pm 0,30$ & $8,13 \pm 0,22$ & $8,00 \pm 0,35$ & $8,13 \pm 0,22$ \\
\hline & $\mathrm{MF}$ & $84,13 \pm 0,35$ & $7,81 \pm 0,13$ & $8,00 \pm 0,28$ & $7,94 \pm 0,19$ & $7,94 \pm 0,13$ \\
\hline & WF & $82,81 \pm 0,44$ & $7,62 \pm 0,40$ & $7,69 \pm 0,25$ & $7,38 \pm 0,33$ & $7,81 \pm 0,37$ \\
\hline \multicolumn{2}{|c|}{ Standard Control } & $81,00 \pm 0,38^{*}$ & $7,25 \pm 0,13$ & $7,75 \pm 0,20$ & $7,00 \pm 0,15$ & $7,50 \pm 0,13$ \\
\hline \multicolumn{2}{|c|}{ Negative Control } & $80,50 \pm 1,23^{* *}$ & $7,25 \pm 0,24$ & $7,31 \pm 0,24$ & $7,25 \pm 0,20$ & $7,50 \pm 0,13$ \\
\hline
\end{tabular}

TABLE 2 - Average values in sensory quality, final score and acidity, fragrance/aroma, body and flavor in coffee samples from the fermentations for $24 \mathrm{~h}$ on coffee pulped in $\mathrm{t} 2$ level delaying time and with different levels of $\mathrm{pH}$ and temperature.

\begin{tabular}{ccccccc}
\hline Temperature & pH & Final score & Acidity & $\begin{array}{c}\text { Fragrance } \\
\text { /aroma }\end{array}$ & Body & Flavor \\
\hline \multirow{2}{*}{17} & 5,0 & $86,63 \pm 0,88^{*}, \mathrm{a}$ & $8,13 \pm 0,18$ & $8,19 \pm 0,18$ & $8,13 \pm 0,18$ & $8,13 \pm 0,18$ \\
& 4,0 & $84,25 \pm 0,71^{\mathrm{ab}}$ & $7,75 \pm 0,00$ & $7,88 \pm 0,18$ & $7,88 \pm 0,18$ & $7,75 \pm 0,00$ \\
& $\mathrm{WC}$ & $83,25 \pm 1,06^{\mathrm{ab}}$ & $7,63 \pm 0,18$ & $8,00 \pm 0,00$ & $7,63 \pm 0,18$ & $7,63 \pm 0,18$ \\
\hline \multirow{2}{*}{23} & 5,0 & $82,75 \pm 2,47^{\mathrm{ab}}$ & $7,63 \pm 0,18$ & $7,75 \pm 0,00$ & $7,50 \pm 0,35$ & $7,50 \pm 0,35$ \\
& 4,0 & $86,00 \pm 1,41^{\mathrm{ab}}$ & $7,88 \pm 0,18$ & $8,13 \pm 0,18$ & $8,00 \pm 0,00$ & $8,25 \pm 0,35$ \\
& $\mathrm{WC}$ & $80,88 \pm 1,59^{\mathrm{b}}$ & $7,13 \pm 0,18$ & $7,75 \pm 0,00$ & $7,25 \pm 0,35$ & $7,38 \pm 0,35$ \\
\hline \multicolumn{2}{c}{ Standard Control } & $81,75 \pm 0,35^{*}$ & $7,50 \pm 0,00$ & $7,75 \pm 0,35$ & $7,25 \pm 0,00$ & $7,50 \pm 0,00$ \\
\hline
\end{tabular}

Values are expressed as mean \pm standard deviation. Means followed by the same letter are not significantly different $(p=0,05)$, according to Tukey's test. *: treatments with significant differences (Dunnett $p=0,05$ ) on the standard control

The other treatments did not present statistical differences in quality probably because of the tight variation range of the temperature and $\mathrm{pH}$ control in the process. Additionally, it is important to consider that, due to the exothermic behavior of the fermentation process, the temperature inside the coffee fermentation tank can increases $4,6{ }^{\circ} \mathrm{C}$ (CORREA et al., 2014) until $8,0^{\circ} \mathrm{C}$ (PEÑUELA et al., 2010; VELMOUROUGANE, 2013) during a fermentation process for $16 \mathrm{~h}$. The changes in this variable along the process can be difficult to control. Generally, the $\mathrm{pH}$ and temperature conditions controlled by the bioreactor generate coffee with quality comparable with that obtained by the effect of fermentation strategies of the first phase.

\section{Organic acid composition}

Most of the acids analyzed in this research are part of the chemical composition of a coffee bean given by fruit metabolic processes (FLAMENT 2002). Quinic, citric, malic and acetic acids were identified as the result of the development and maturity process of coffee fruits (ROGERS et al., 1999). Conversely, lactic acid in coffee has been related with metabolic activity of microorganisms (LÓPEZ et al., 1989, AVALLONE et al., 2001; EVANGELISTA et al., 2015; JACKELS; JACKELS, 2005; PEREIRA et al., 2016). However, all acids identified can also can be substrates or precursors related to the 
different fermentation processes assessed. The concentrations of quinic, citric and malic acids determined in this research were in the average values reported from the green beans of Arabica coffee $(5,5,7,6$ and $4,1 \mathrm{mg} / \mathrm{g}$ d.b., respectively) (JHAM et al., 2002; ROGERS et al., 1999).

Tables 3 and 4 present the acid concentration values corresponding to the average obtained by the extraction of the samples at the end of each treatment. The final concentrations of quinic, malic and succinic acids did not present variations that can be attributed to the fermentation strategies evaluated. The interaction among the factors, pulping delaying time and fermentation method significantly affected the concentrations of lactic, acetic and citric acids $(p<0,0001,0,0031$ and 0,0357 , respectively) (Table 3 ). Treatments with longer times (t1-MF, t1-WF, t2-MF and t2-WF) showed the highest concentration of acetic and citric acids, meanwhile the greatest accumulation of lactic acid was associated to the longest pulping delaying time used in the evaluation.

In the same way, the fermentations conducted under combination of temperature and $\mathrm{pH}$ control in the bioreactor (Table 4), ANOVA showed a significant effect on the malic, quinic, lactic and acetic acid concentrations $(p=0,0007$, $0,0006,0,0002$ and $<0,0001$, respectively).

TABLE 3 - Organic acid concentrations ( $\mathrm{mg} / \mathrm{g}$ of coffee d.b.) in coffee samples from different fermentation strategies.

\begin{tabular}{|c|c|c|c|c|c|c|c|}
\hline $\begin{array}{c}\text { Time } \\
\text { before } \\
\text { pulping }\end{array}$ & $\begin{array}{l}\text { Fermentation } \\
\text { method }\end{array}$ & Acetic acid & Lactic acid & Citric acid & Malic acid & $\begin{array}{l}\text { Succinic } \\
\text { acid }\end{array}$ & Quinic acid \\
\hline \multirow{3}{*}{$\mathrm{t} 1$} & F24 & $(12,00 \pm 0,78)^{b^{*}, * *}$ & $(2,93 \pm 0,10)^{\mathrm{c}^{* *}}$ & $(4,43 \pm 2,18)^{b}$ & $1,53 \pm 0,80$ & $1,31 \pm 0,20$ & $5,17 \pm 1.53$ \\
\hline & MF & $(25,48 \pm 1,01)^{a^{*, * *}}$ & $(4,36 \pm 0,26)^{\mathrm{c}}$ & $(6,45 \pm 0,27)^{\mathrm{a}}$ & $2,01 \pm 0,26$ & $1,62 \pm 0,27$ & $5,83 \pm 0,22$ \\
\hline & WF & $(24,89 \pm 2,76)^{a^{*, * *}}$ & $(7,45 \pm 1.39)^{b^{*}}$ & $(4,82 \pm 0,23)^{\mathrm{ab}}$ & $1,63 \pm 0,09$ & $0,43 \pm 0,13$ & $5,51 \pm 0,56$ \\
\hline \multirow{3}{*}{$\mathrm{t} 2$} & F24 & $(16.86 \pm 6.62)^{a b *, * *}$ & $(8,40 \pm 0,99)^{b^{* * * * *}}$ & $(3,12 \pm 1,38)^{b}$ & $1,13 \pm 0,78$ & $1,46 \pm 0,89$ & $4,28 \pm 1.79$ \\
\hline & MF & $(22,92 \pm 2,40)^{a^{* * * *}}$ & $(9,93 \pm 0,54)^{a^{*, * *}}$ & $(4,03 \pm 1,68)^{b}$ & $1,16 \pm 0,62$ & N.D. & $4,29 \pm 0,50$ \\
\hline & WF & $(20,16 \pm 2.87)^{\mathrm{ab}^{*, * * *}}$ & $(10,93 \pm 0,21)$ & $(4,43 \pm 1,29)^{\mathrm{b}}$ & $1,41 \pm 0,70$ & N.D. & $4,26 \pm 0,99$ \\
\hline \multicolumn{2}{|c|}{ Standard Control } & $4,69 \pm 0,41$ & $6,01 \pm 0,27$ & $5,23 \pm 0,98$ & $1,37 \pm 0,49$ & $1,48 \pm 0,28$ & $5,24 \pm 0,07$ \\
\hline \multicolumn{2}{|c|}{ Negative Control } & $2,31 \pm 0,25$ & $4,88 \pm 0,25$ & N.D. & N.D. & N.D. & $5,54 \pm 0,00$ \\
\hline
\end{tabular}

Values are expressed as mean \pm standard deviation. Means followed by the same letter are not significantly different $(p=0,05)$, according to Tukey's test. *: treatments with significant differences (Dunnett $p=0,05)$ on the standard control. **: treatments with significant differences (Dunnett $p=0,05$ ) on the negative control. N.D: Not detected

TABLE 4 - Organic acid concentrations ( $\mathrm{mg} / \mathrm{g}$ of coffee d.b.) in coffee samples from fermentation processes for $24 \mathrm{~h}$ on coffee pulped in $\mathrm{t} 2$ level delaying time at distinct levels of $\mathrm{pH}$ and temperature

\begin{tabular}{cccccccc}
\hline Temperature & $\mathrm{pH}$ & Acetic acid & Lactic acid & Quinic acid & \multicolumn{2}{c}{ Malic acid } & Citric acid Succinic acid \\
\hline \multirow{2}{*}{$17^{\circ} \mathrm{C}$} & 5,0 & $(12,38 \pm 0,47)^{\mathrm{bc}}$ & $(0,95 \pm 0,19)^{\mathrm{b}}$ & $(3,48 \pm 0,16)^{\mathrm{bc}}$ & $0,38 \pm 0,05^{\mathrm{b}, *}$ & $1,82 \pm 0,56$ & $0,27 \pm 0,01$ \\
& 4,0 & $(12,74 \pm 0,56)^{\mathrm{abc}, *}$ & $(3,76 \pm 0,24)^{\mathrm{a}}$ & $(3,63 \pm 0,44)^{\mathrm{abc}}$ & $0,43 \pm 0,06^{\mathrm{b}, *}$ & $2,28 \pm 0,03$ & $1,18 \pm 0,11$ \\
& W.C. & $(11,15 \pm 0,40)^{\mathrm{c}}$ & $(1,23 \pm 0,19)^{\mathrm{b}}$ & $(2,99 \pm 0,17)^{\mathrm{c}}$ & $1,07 \pm 0,01^{\mathrm{a}}$ & $1,69 \pm 0,10$ & $0,33 \pm 0,18$ \\
\hline \multirow{2}{*}{$2{ }^{\circ} \mathrm{C}$} & 5,0 & $(14,33 \pm 0,67)^{\mathrm{abc}, *}$ & $(3,58 \pm 1,29)^{\mathrm{a}, *}$ & $(3,95 \pm 0,13)^{\mathrm{ab}, *}$ & $0,28 \pm 0,10^{\mathrm{b}, *}$ & $1,70 \pm 0,42$ & N.D. \\
& 4,0 & $(15,05 \pm 1,73)^{\mathrm{a},{ }^{*}}$ & $(3,94 \pm 1,02)^{\mathrm{a},{ }^{*}}$ & $(4,51 \pm 0,36)^{\mathrm{a}, *}$ & $0,38 \pm 0,21^{\mathrm{b}, *}$ & $2,45 \pm 1,12$ & $0,09 \pm 0,01$ \\
& W.C. & $(14,36 \pm 1,03)^{\mathrm{ab}}$ & $(4,10 \pm 0,30)^{\mathrm{a}, *}$ & $(3,89 \pm 0,93)^{\mathrm{abc}}$ & $0,43 \pm 0,05^{\mathrm{b}, *}$ & $1,71 \pm 0,61$ & N.D. \\
\hline \multicolumn{2}{l}{ Standard Control } & $12,51 \pm 2,05$ & $1,35 \pm 0,68$ & $3,15 \pm 0,40$ & $2,06 \pm 1,06$ & $4,07 \pm 0,55$ & $0,56 \pm 0,19$ \\
\hline
\end{tabular}

Values are expressed as mean \pm standard deviation. Means followed by the same letter are not significantly different at $p=0,05$, according to Tukey's test. *: Treatments with significant differences on the standard control (SC), according to Dunnett test at $p=0,05$. N.D: Not detected 
The highest values of acetic, lactic and quinic acid seemed to be associated with a high fermentation temperature. The treatment performed at $17{ }^{\circ} \mathrm{C}$ and $\mathrm{pH} 5,0$ obtained the most representative difference given by the low concentration of lactic acid. Furthermore, the main differences with the standard control were obtained with the coffee from fermentations conduced to $23{ }^{\circ} \mathrm{C}$.

The previous results are explained as follows. Quinic acid is part of the natural chemical composition of green coffee beans, as it forms the molecular structure of chlorogenic acids along with caffeic acid. The quinic acid concentration was not altered by the fermentation processes applied in the first part of this study. Consequently, the microorganisms that contributed in the treatments did not use quinic acid as a carbon source. Nevertheless, under the conditions of the bioreactor, treatments at $17{ }^{\circ} \mathrm{C}$ showed a slight decrease in quinic acid compared with the other fermentation processes. This result suggests that microbial population could be stimulated under these conditions and use this compound as a substrate, reducing its concentration. Conversely, the increase in quinic acid concentration in coffee is directly related to the degradation of chlorogenic acids during roasting; this compound is also related to the astringency and body of coffee (SCA 2015).

Citric and malic acids produce a beverage with pronounced acidity. However, they are not desirable in high concentrations because they can create an acidic and astringent taste (FLAMENT, 2002). These acids presented higher values in t1MF. The concentration of succinic acid seemed to be associated with the low process time or low fermentation temperature, as this compound was not detected during longer fermentation and when the process temperature was $23^{\circ} \mathrm{C}$.

Conversely, the variation in the fermentation strategy directly affected the acetic acid production, as demonstrated by the difference in concentration between the treatments and the controls (Dunnett test). The higher levels of acetic acid were related to higher process times (t1MF, t1-WF, t2-WF and t2-MF) or with a higher fermentation temperature $\left(23^{\circ} \mathrm{C}\right)$. Other studies reported that the accumulation of this compound in coffee occurs in the environmental temperature of $22{ }^{\circ} \mathrm{C}$ or when the fermentation time is greater than $20 \mathrm{~h}$ (BERTRAND et al., 2012). High acidity is known to be produced during fruit development and in the fermentation of coffee grown at high altitudes (low temperature) (BERTRAND et al., 2006). This condition has been found to influence the environmental conditions of some compounds in coffee, such as chlorogenic acids, lipids and sugars (JOËT et al., 2010). The concentrations of some organic acids are presumed to have the same behavior. The presence of acetic acid in coffee is related to the vinegar taste in the beverage; therefore, its excess production during fermentation is not recommended. During the fermentation process carried out for over $44 \mathrm{~h}$, overfermented coffee beans and a vinegar taste were present along with an acetic acid concentration of 0,471 $\mathrm{mg} / \mathrm{mL}$ (LÓPEZ et al., 1989). This value is higher than that reported in the current research $(25,48$ $\mathrm{mg} / \mathrm{g}$ coffee d.b. or $0,172 \mathrm{mg} / \mathrm{mL}$ ). Furthermore, none of the coffee samples analyzed in the sensory analysis reported a vinegar taste or a defect in cup.

In lactic acid production, the fermentation conditions at the highest temperature $\left(23^{\circ} \mathrm{C}\right)$ or the longest processing time, including the addition of water at the end of the process, generated a high concentration of this compound. Lactic acid is as a product of fermentation that increases during the process time, and its accumulation has been related to the decline of the $\mathrm{pH}$ value (AVALLONE et al., 2001; JACKELS; JACKELS, 2005; PEREIRA et al., 2016). Lactic acid bacteria are included in the microbial community involved in coffee fermentation (AVALLONE et al., 2001; EVANGELISTA et al., 2015; LÓPEZ et al., 1989; PEREIRA et al., 2016). The highest concentration of lactic acid coincided with the $\mathrm{pH}$ value of 3,77 in coffee fermentation mass.

The processes assessed showed that changing the development of fermentation is possible. Changes in the organic acid concentrations support this claim. In addition, CHAVERRA, (2016) found that microbial composition associated with these coffee fermentations changed according to the different conditions applied.

The spatial map generated by the application of Multidimensional Scaling (MDS) in the six organic acid concentrations facilitated the understanding of the relationship among the different coffee fermentation processes (Figure 1). Points that are close together represent similar treatments. Points far apart represent dissimilar treatments. For the fermentation strategies, (Figure 1a) coffee was classified into three groups, and one treatment (t1-F24) that coincided with the low concentration of lactic acid. Group 1 corresponded to the standard and negative controls, these treatments had the lowest means of acetic acid and the lowest final score. 
(a)
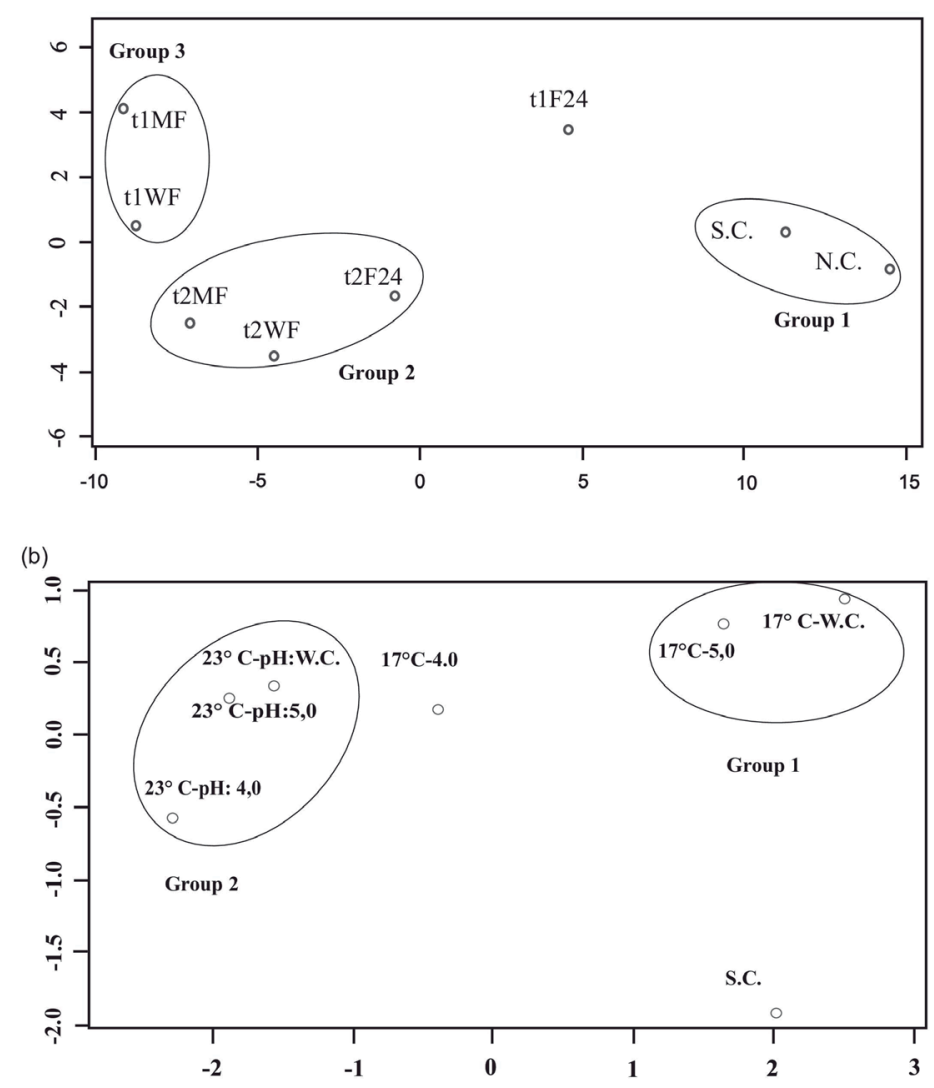

FIGURE 1 - Similarity map of coffee samples according to organic acid concentrations obtained from (a) different fermentation strategies and (b) fermentations with different levels of $\mathrm{pH}$ and temperature.

The groups 2 and 3 was composed of treatments with different level of pulping delaying time thus indicating the effect of this condition on the composition of organic acids in green coffee beans, furthermore, were associated with coffee quality. The groups coincided with a high lactic acid concentration (Group 2) and the highest mean concentrations of acetic and malic acids (Group 3); the coffee from Group 3 was classified as specialty. Figure $1 \mathrm{~b}$ shows two groups and two individual treatments. These groups reflected the effect of temperature on organic acid concentrations; because of the groups were conformed by treatments with the same level of temperature and similar concentrations of acetic and lactic acids mainly. Moreover, the graphical representation shows the dissimilarities between the control treatments and the coffee obtained by different methods to conduct the fermentation processes. The standard control and the treatment $17^{\circ} \mathrm{C}$ and $\mathrm{pH} 4,0$ were different from the groups; because both had intermediate values of acetic acid and high lactic acid concentrations. Finally, the application of MDS correctly classified the coffee treatments according to the different fermentation processes, and it coincided with the results of coffee quality, especially the dissimilarities found in the control treatments.

\section{Volatile Organic Compounds}

Twenty-two volatile compounds were identified by the HS-SPME/GC-MS, which were grouped in eight alcohols, seven esters, three aldehydes, two acids and two ketones (Table 5). The compounds associated with thermal origin in green coffee such as furans and pyrroles, are produce in the drying stage, because they were not found in the freeze-dried samples (lyophilisation). Most of the compounds have been identified in green coffee beans and linked with the postharvest process (FLAMENT, 2002;), especially with the fermentation stage (GONZALEZ-RIOS et al., 2007). Alcohols and esters were the most abundant in the HS of green coffee, mainly ethanol and ethyl acetate, respectively. 
TABLE 5 - Average values of Volatile Organic Compounds (VOCs) contents (Arbitrary Units x $10^{5}$ ) identified by HS-SPME/GC-MS in samples of green coffee obtained by different fermentation processes

\begin{tabular}{|c|c|c|c|c|c|c|c|}
\hline Compound & t2-F24 & t2-WF & $\begin{array}{c}17^{\circ} \mathrm{C} \\
\text { pH } 5,0\end{array}$ & $\begin{array}{c}23^{\circ} \mathrm{C} \\
\text { pH } 4,0\end{array}$ & $\begin{array}{c}23^{\circ} \mathrm{C} \\
\text { pH SC }\end{array}$ & $\begin{array}{c}\text { Standard } \\
\text { Control }\end{array}$ & $\begin{array}{c}\text { Negative } \\
\text { Control }\end{array}$ \\
\hline Acetic acid & 1637,0 & 490,1 & 508,1 & 941,2 & 1438,3 & 1246,7 & 121,4 \\
\hline Pentanoic acid & 45,4 & 17,9 & 76,4 & 60,9 & 46,0 & 150,4 & 27,2 \\
\hline Methanol & 201,7 & 183,3 & 344,2 & 99,9 & 206,0 & 206,9 & 84,0 \\
\hline Ethanol & 6050,2 & 6376,6 & 4078,3 & 4517,4 & 3600,6 & 1759,6 & 256,8 \\
\hline 1-Propanol & 13,8 & 8,8 & 13,4 & 26,9 & 16,4 & 12,5 & 0,3 \\
\hline 1-Butanol & 11,1 & 7,8 & 18,4 & 13,3 & 10,4 & 58,7 & 0,1 \\
\hline 1-Penten-3-ol & 16,0 & 6,4 & 7,4 & 12,6 & 9,3 & 0,1 & 2,3 \\
\hline 2-Methyl-1-propanol & 43,2 & 14,1 & 24,3 & 61,4 & 21,1 & 33,0 & 0,4 \\
\hline 3-Methyl-1-butanol & 25,4 & 10,6 & 28,4 & 38,2 & 10,4 & 39,9 & 2,0 \\
\hline 3-Methyl-2-buten-1-ol & 6,4 & 1,3 & 12,2 & 4,5 & 7,4 & 27,5 & 3,0 \\
\hline Ethyl-formate & 5,0 & 1,1 & 1,4 & 3,7 & 3,1 & 4,4 & 0,3 \\
\hline Methyl-acetate & 123,3 & 13,8 & 104,5 & 58,1 & 59,3 & 145,9 & 0,2 \\
\hline Ethyl-acetate & 5068,3 & 593,3 & 1482,0 & 3086,5 & 583,2 & 820,1 & 1,8 \\
\hline Methyl-lactate & 9,1 & 5,4 & 1,7 & 1,0 & 7,8 & 4,0 & 0,0 \\
\hline Ethyl-lactate & 103,8 & 44,6 & 9,4 & 14,4 & 26,6 & 1,5 & 0,3 \\
\hline 3-Methyl-1-Butanol acetate & 22,3 & 13,0 & 4,4 & 22,0 & 3,9 & 11,4 & 7,6 \\
\hline Ethyl-isovalerate & 30,3 & 23,7 & 69,5 & 106,9 & 22,3 & 45,1 & 0,4 \\
\hline Acetaldehyde & 58,9 & 106,3 & 177,9 & 116,4 & 41,7 & 183,1 & 28,8 \\
\hline 2-Methyl-propanal & 3,7 & 5,1 & 42,2 & 5,3 & 2,5 & 68,5 & 0,7 \\
\hline n-Hexanal & 9,8 & 4,0 & 19,8 & 4,9 & 3,8 & 18,8 & 3,1 \\
\hline 2,3-Butanodione & 33,6 & 7,4 & 13,7 & 51,3 & 7,6 & 31,7 & 7,8 \\
\hline 3-Hydroxy-2-butanone & 267,3 & 47,0 & 52,3 & 613,1 & 92,4 & 271,8 & 54,8 \\
\hline
\end{tabular}

Furthermore, these chemical classes are important because of their aroma prolife is related with pleasant, fruity and floral notes. The acids, alcohols and esters were formed mainly because of microbial activity. Therefore, the lowest values of these chemical classes were for the negative control (without fermentation), which also had the lowest value in the fragrance attribute.

Composition of green coffee beans from the fermentation processes was different and produced samples richer in volatile compounds. Even though the alcohols were the main chemical class, different concentrations in the other classes were found. For example, the main compounds of the samples corresponding to highest quality qualification (t2-F24, $17^{\circ} \mathrm{C}-\mathrm{pH} 5,0$ and $23^{\circ} \mathrm{C}-$ $\mathrm{pH} 4,0)$ were esters mainly ethyl acetate, ethyl isovalerate and 3-methyl-1-butanol acetate (isoamyl acetate) which fruity odor. On the other hand, ketones (3-hydroxy-2-butanone and 2,3 butanodione) in the sample corresponding to 23 ${ }^{\circ} \mathrm{C}$-pH 4,0, can be considerate important given their characteristics of aroma. These treatments as part of Group 1, agree with the MDS analyzes (Figure 2).

On the other hand, samples corresponding to lowest quality score showed a higher concentration of aldehydes and acids, such as acetic acid, and acetaldehyde and hexanal, the latter related with insect damaged beans, which can cause undesirable flavors and odors (TOCI; FARAH, 2008). The similarity map shows the Group 2, composed by the samples corresponding to control treatments, exhibited low concentrations of alcohols, esters and ketones. In addition, the similarity map also shows two treatments with dissimilarity; t2-WF and $23{ }^{\circ} \mathrm{C}-\mathrm{pH} \mathrm{WC}$, that differ mainly in the alcohols and acids content. 


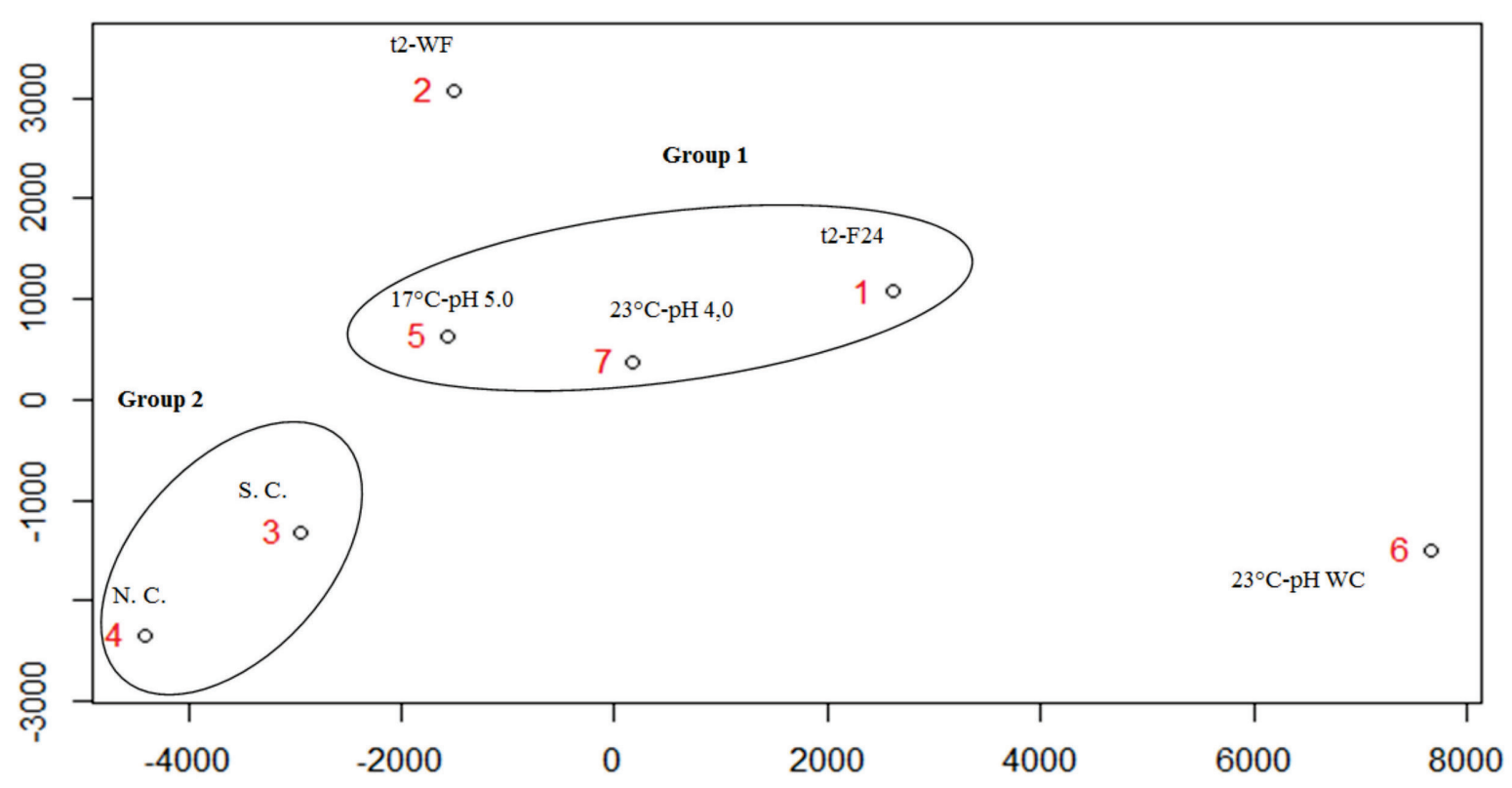

FIGURE 2 - Similarity map of coffee samples according to Volatile Organic Compounds (VOCs) contents.

Different contents of compounds in the samples suggest the possibility of modifying the composition through fermentation processes conducted under different conditions. These results suggest changes in microbial activity in the processes, given the variations to perform the fermentations. A similar behavior was observed in the composition of volatile organic compound from green coffee beans inoculated with yeast in dry method (EVANGELISTA et al., 2014) and in different regions of coffee production in Brazil with different conditions of air temperature (EVANGELISTA et al., 2015).

It is known that the aroma and taste of coffee develop during roasting (RIBEIRO et al., 2009). However, the final quality depends on the quality of the green bean, which in turn shows the characteristics given by the species and process type, in which fermentation has an important part in the formation of compounds as result of the metabolism of the microorganisms in the process. The utility of the results shown in this research work demonstrate the possibility of improving the coffee quality by using different fermentation techniques.

\section{CONCLUSIONS}

The fermentation processes assessed increased the coffee quality regarding the control treatments. Therefore, this study is the first to show that variations in the coffee fermentation process and variables control, such as $\mathrm{pH}$ and temperature, increase the coffee quality under the environmental conditions, variety and methods applied in this research.

The fermentations applied facilitated the production of organic acids as substrates or precursors along with organic compounds, depending on the carried fermentation process. The results suggest that is possible modulate the beverage acidity as well as the fragrance/aroma through organic acids production and alcohols, esters, ketones in a synergistic combination, and this can promote differentiated profiles in order to satisfy the requirements of specialty coffees.

Finding the best strategy to conduct fermentation processing is possible without requiring microorganism inoculation, which becomes a complex process in the conditions of coffee farms. Acetic acid was the main compound that changed its concentration because of variations in the fermentation process. The concentrations of the acids identified were not associated with quality damage.

\section{ACKNOWLEDGEMENTS}

The authors thank the sponsors of the project "Antioquia, the origin of specialty coffee" from the Antioquia Government, for the finantial support, which was carried out with resources from the "Fondo Nacional de Regalías" through the association agreement with Universidad Nacional de Colombia (4600000539). Additionally, to Aristofeles Ortíz, Scientific researcher in Centro Nacional de Investigaciones de Café- Cenicafé. 


\section{REFERENCES}

AVALLONE, S. et al. Microbiological and biochemical study of coffee fermentation. Current Microbiology, v. 42, n. 4, p. 252-256, Apr. 2001.

BERTRAND, B. et al. Comparison of bean biochemical composition and beverage quality of Arabica hybrids involving Sudanese-Ethiopian origins with traditional varieties at various elevations in Central America. Tree Physiology, v. 26, n. 9, p. 1239-1248, Sept. 2006.

BERTRAND, B. et al. Climatic factors directly impact the volatile organic compound fingerprint in green Arabica coffee bean as well as coffee beverage quality. Food Chemistry, v. 135, n. 4, p. 2575-2583, Dec. 2012.

CAIXETA, I. F.; GUIMARES, R. M.; MALTA, M. R. Quality of coffee seeds after retardment of post-harvest processing. Coffee Science, Lavras, v. 8, n. 3, p. 249255, July./Sept. 2013.

CHAVERRA, L. Determinación of microbiota asociada con diferentes metodos de fermentación en café para la producción de cafés especiales en Antioquia, Colombia. 2016. 115 p. Thesis (Master in Sciences Biotechnology). Universidad Nacional de Colombia, sede Medellín, Medellín, 2016.

CORDOBA-CASTRO, N. M.; GUERREROFAJARDO, J. E. Caracterización de los procesos tradicionales de fermentación de Café en el departamento de Nariño. Biotecnología en el Sector agropecuario y agroindustrial, v. 14, n. 2, p. 75-83, July./Dec. 2016.

CORREA, E. C. et al. Advanced Characterization of a Coffee Fermenting Tank by Multi-distributed Wireless Sensors: Spatial Interpolation and Phase Space Graphs. Food Bioprocess Technology, New York. v. 7, n. 11, p. 3166-3174, Nov. 2014.

EVANGELISTA, S. R. et al. Microbiological diversity associated with the spontaneous wet method of coffee fermentation. International Journal of Food Microbiology, v. 210, p. 102-112, Oct. 2015.

EVANGELISTA, S. R. et al. Improvement of coffee beverage quality by using selected strains during the fermentation in dry process. Food Research International, v. 61, p. 183-195, July. 2014.

FLAMENT I. Coffee Flavor Chemistry. Chichester: John Wiley \& Sons, 2002. 319 p.
FOLMER, B. How can Science help to create new value in Coffee? Food Research International. v. 63, part C, p. 477-482, Sept. 2014.

GONZALEZ-RIOS, O. et al. Impact of "ecological" post-harvest processing on the volatile fraction of coffee beans: I. Green coffee. Journal of Food Composition and Analysis, v. 20, n. 3/4, p. 289-296, May. 2007.

ISO 6673 Green coffee - Determination of the loss in mass at $105{ }^{\circ} \mathrm{C}$ of green coffee. International Organization for Standardization, Switzerland. 2003.

JACKELS, S. C.; JACKELS, C. F. Characterization of the coffee mucilage fermentation process using chemical indicators: a field study in Nicaragua. Journal of Food Science. v. 70, n. 5, p. C321-C325, June. 2005.

JOËT, T. et al. Influence of environmental factors, wet processing and their interactions on the biochemical composition of green Arabica coffee beans. Food Chemistry. v. 118, n. 3, p. 693-701, Feb. 2010.

KNOPP, S.; BYTOF, G.; SELMAR, D. Influence of processing on the content of sugars in green Arabica coffee beans. European Food Research and Technology, v. 223, n. 2, p. 195-201, June. 2006.

LEE, L. W. et al. Coffee fermentation and flavor - An intricate and delicate relationship. Food Chemistry, v. 185, p. 182-191, Oct. 2015.

LIN, C. Approach of Improving Coffee Industry in Taiwan-Promote Quality of Coffee Bean by Fermentation. The Journal of International Management Studies, v. 5, n. 1, p. 154-159. 2010

LÓPEZ, C. I. Factors related to the formation of "overfermented coffee beans" during the wet processing method and storage of coffee. In: Proceedings of the 13th International Scientific Colloquium on Coffee ASIC. Paipa, 1989. p. 373-384.

PEÑUELA, A. E. et al. Evaluación de una enzima pectinolítica para el desmucilaginado del café. Cenicafé v. 61, n. 3, p. 241-250. 2010.

PEÑUELA, A. E; OLIVEROS, C. E.; SANZ, J. R. Remoción del mucílago de café a través de fermentación natural. Cenicafé, v. 61, n. 2, p. 159-173. 2010

PEÑUELA, A. E.; SANZ, J. R.; PABÓN, J. P. Método para identificar el momento final de la fermentación de mucílago de café. Cenicafé, v. 63, n. 1, p. 120-131. 2012. 
PEREIRA, G. V. de M. et al. Potential of lactic acid bacteria to improve the fermentation and quality of coffee during on-farm processing. International Journal of Food Science and Technology, v. 51, n. 7, p. 1689-1695, July. 2016

PEREIRA, G. V. de M. et al. Conducting starter culture-controlled fermentations of coffee beans during on-farm wet processing: Growth, metabolic analyses and sensorial effects. Food Research International, v. 75, p. 348-356, Sept. 2015.

PEREIRA, L. L. et al. The consistency in the sensory analysis of coffees using Q-graders. European Food Research and Technology, v. 243, n. 9, p. 1545-1554, Sept. 2017.

POLTRONIERI, P.; ROSSI, F. Challenges in Specialty Coffee Processing and Quality Assurance. Challenges, v. 7, n. 19 , p. 2-22, Oct. 2016

RIBEIRO, J. S. et al. Prediction of sensory properties of Brazilian Arabica roasted coffees by headspace solid phase microextraction-gas chromatography and partial least squares. Analytica Chimica Acta, v. 634, n. 2, p. 172-179, Feb. 2009.

RODRIGUES, N. P.; BRAGAGNOLO, N. Identification and quantification of bioactive compounds in coffee brews by HPLC-DAD-MSn. Journal of Food Composition and Analysis, v. 32, n. 2, p. 105-115, Dec. 2013.

ROGERS, W. J. et al. Changes to the content of sugars, sugar alcohols, myo-inositol, carboxylic acids and inorganic anions in developing grains from different varieties of Robusta (Coffea canephora) and Arabica (C. arabica) coffees. Plant Science, v. 149, n. 2, p. 115-123, Dec. 1999.

SELMAR, D. et al. Germination of Coffee Seeds and its Significance for Coffee Quality. Plant Biology, v. 8, n. 2, p. 260-264, Mar./Apr. 2006.
SILVA, C. F. et al. Evaluation of a potential starter culture for enhance quality of coffee fermentation. World Journal of Microbiology and Biotechnology, v. 29, n. 2, p. 235-247, Feb. 2013.

SPECIALTY COFFEES ASSOCIATION OF AMERICA. SCA Protocols. Cupping Specialty Coffee. SCA, 2015. Available in: $<$ http://www.scaa. org/PDF/resources/cupping-protocols.pdf $>$. Access in: November 2017.

SUNARHARUM, W. B.; WILLIAMS, D. J.; SMYTH, H. E. Complexity of coffee flavor: A compositional and sensory perspective. Food Research International, v. 62, p. 315-325, Aug. 2014.

TAI, E. S.; HSIEH, P. C.; SHEU, S. C. Effect of polygalacturonase and feruloyl esterase from Aspergillus tubingensis on demucilage and quality of coffee beans. Process Biochemistry. v. 49, n. 8, p. 1274-1280, Aug. 2014.

TOCI, A. T.; FARAH, A. Volatile compounds as potential defective coffee beans' markers. Food chemistry, v. 108, n. 3, p. 1133-1141, June. 2008.

TOLEDO, P. R. A. B. et al. Relationship between the Different Aspects Related to Coffee Quality and Their Volatile Compounds. Comprehensive Reviews in Food Science and Food Safety, v. 15, n. 4, p. 705-719, July./Aug. 2016.

VELMOROUGANE K. et al. Use of starter culture in coffee fermentation - effect on demucilisation and cup quality. India Coffee, v. 72, p. 31-34. 2008.

VELMOUROUGANE, K. Impact of Natural Fermentation on Physicochemical, Microbiological and Cup Quality Characteristics of Arabica and Robusta Coffee. Proceedings of the National Academy of Sciences India, v. 83, n. 2, p. 233-239, Apr./June. 2013. 